\title{
On the relationship between compliance \\ with recommendations on the audit committee of codes of good practices and financial reporting quality
}

\author{
Josep Garcia-Blandon · Josep Maria Argilés-Bosch· Monica \\ Martinez-Blasco $\cdot$ David Castillo Merino
}

\begin{abstract}
Codes of good practices provide a soft alternative to the hard legislation approach to corporate governance. These codes include a set of recommendations that companies are expected to follow in order to enhance governance structures and practices. Some of these recommendations specifically aim to improve the effectiveness of the audit committee. We investigate the relationship between the level of compliance with recommendations on the audit committee of the Spanish Unified Code and financial reporting quality, as measured by discretionary accruals and by the opinion of the audit report. We use a sample of companies listed in the Span- ish stock market for the years between 2007 and 2013. Results show a strong and positive relationship between the level of compliance with recommendations and the quality of financial reporting. We also report significant results for some specific recommendations. These results are robust to various checks. Therefore, the level of compliance with recommendations on the audit committee might provide a feasible and reliable indicator of the quality of financial reports released by the company.
\end{abstract}

Keywords Codes of good practices · Recommendations · Audit committee · Financial reporting quality 


\section{Introduction}

The Enron case and other financial scandals at the beginning of this century caused a great concern among regulators and policy-makers about the necessity of new regulations to prevent, or at least to make it difficult, such cases to repeat. A common feature of these scandals was that the accounting information released by the companies did not reflect the current economic and financial situation. Thus, market participants who made investment decisions on the basis of this information were being tricked by managers, the ultimate responsible of the accounting information produced and released by the company.

As posed by Aguilera \& Cuervo-Cazurra (2009), loss of confidence in accounting information, caused by these corporate scandals, favoured an increasing demand for sounder corporate governance structures and practices. They argued that the reaction of regulators to these demands has been twofold. On the one hand, through the approval of "hard legislation", such as the Sarbanes-Oxley Act (hereinafter SOX $\mathrm{Act}^{1}$ ) aiming to improve governance practices which should ultimately lead to higher accounting quality. On the other hand, and usually complementing this hard approach, the approval and endorsement of codes of good practices (hereinaf- ter, CGP) has been a "soft legislation" reaction to the demand of better governance. These codes constitute non-binding set of principles, standards or best practices, issued by a collective body, and relating to the internal governance of corporations (Weil and Manges 2002).

Both hard and soft legislation approaches emphasize the role of the audit committee in guaranteeing the quality of accounting information. DeFond \& Zhang (2014, 306) argued that a major consequence of the SOX Act was to raise public awareness of the role auditing plays in effective corporate governance. The most visible sign of this upgrade in the status of the auditing profession being the mandated changes to the audit committee. These changes attempted to increase the demand for auditquality by improving client governance. A number of studies have investigated whether financial reporting quality has improved as a result of these requirements (e.g. Klein 2002, Abbott et al. 2004 and more recently, De Vlaminck \& Sarens 2015). As for the soft legislation approach, CGP generally include a bunch of recommendations on the audit committee. As an example, the Spanish 2006 Unified Good Governance Code of Listed Companies (hereinafter "Unified Code") (CNMV 2006) included eight recommendations (out of 58) specifically referring to the audit committee, and

\footnotetext{
${ }^{1}$ The Law contains numerous measures aiming to enhance the quality of accounting information. Among others: CEO and chief financial officer must certify financial statements; all audit commit- tee members must be outside independent directors; and the lead partner of the audit team must change every five years.
} 
the 2015 reform of the Unified Code (CNMV 2015) further expands the powers of the audit committee and it also establishes new requirements.

The motivation of this study lies on the growing importance of corporate governance issues not only among scholars on management, but also for regulators and policy makers. This situation has led, among other things, to the approval and endorsement of CGP in many countries. An area of particular concern is the quality of the financial information produced and released by corporations. If the level of compliance with CGP recommendations effectively indicates stronger governance mechanisms and structures, investors, market participants and any potential stakeholder might use this easily accessible information as an indicator of the quality of a company's governance. Nevertheless, to the best of our knowledge, no study to date has examined to what extent, compliance with the recommendations of CGP is in fact associated with higher financial reporting quality. We aim to contribute not only to the literature but also to corporate governance practice by addressing this gap. With this goal, we investigate the relationship between compliance with recommendations on the audit committee of the Unified Code and financial reporting quality. We conduct the empirical analysis with a sample of Spanish listed companies for the years between 2007 and 2013, and use two proxies for financial reporting quality: discretionary accruals and the opinion of the audit report.

In anticipation of the results, we find a strong and positive association of the level of compliance with recommendations with the quality of financial reports. This result seems robust as it holds for both proxies of financial reporting quality. Moreo- ver, in the study conducted at the individual recommendations level we observe sig- nificant effects for some specific recommendations. Therefore, we should conclude that compliance with recommendations seems to provide a feasible and reliable indi- cator of the quality of financial reports.

The remaining of the paper is organized as follows. The next section summarizes the main features of the Unified Code. Next, section three reviews the related literature and develops the hypotheses of this research. The design of the empirical analysis is presented in section four. In section five we discuss the results and, in the last section, conclusions are drawn.

\section{The spanish unified code}

The first Spanish CGP was approved in February 1998 in response to the social demand for more efficiency, agility and transparency from the companies (Rodriguez-Fernandez 2016). Officially named Spanish Code of Best Practices, was usually known as the Olivencia Code. It contained 23 recommendations on responsibilities, structure and organization of the board of directors. As in other countries, compliance with the recommendations was purely voluntarily. Later on, in 2002, the Aldama Commission was created in order to assess the level of compliance of the Olivencia Code and to propose provisions to enhance transparency and secu- rity in the stock market. In 2003, the Commission released the so-called Aldama Report, which concluded that good practice in corporate governance should remain in the self-regulation sphere, subject to the "comply or explain" approach but 
complemented by certain mandatory rules ${ }^{2}$ (CNMV 2004). Following the Aldama Report, a number of corporate governance rules found their way into legislation.

In 2003 the Spanish Government required the CNMV to draft a single docu- ment on good corporate governance practices that would consolidate the contents of both, the Olivencia Code and the Aldama Report. The result was the Unified Code released in May 2006. It includes 58 recommendations classified into five main areas: company bylaws and general shareholders' meetings (six recommendations); structure and operation of the board of directors (20 recommendations); directors (eight recommendations); remuneration of directors and senior officers (seven recommendations) and committees (17 recommendations). Following the approval of the Unified Code, listed companies have to take these 58 recommendations as benchmarks. According to the 2012 report of the (CNMV 2012), companies were compliant, on average, with 81 percent of the recommendations. In 2015 the CNMV published a reform of the Unified Code (CNMV 2015) which, among other changes, expands the powers of the audit committee.

According to the aim of this paper, the focus on the following recommendations: \#46 (on the accounting background of the members of the audit committee), \#47 (on the internal audit function supervised by the audit committee), \#48 (on the head of internal audit presenting the annual work program to the audit committee), \#49 (on the minimum content of the control and risk management policy), $\# 50$ (on the role of the audit committee), \#51 (on the powers of the audit committee), \#52 (on the information to be prepared by the audit committee) and \#53 (on the board of directors aiming to present the annual accounts with an unqualified audit report). Weprovide the exact definition of each recommendation in the Appendix.

As they are defined in the Unified Code, compliance with some of these recommendations is rather subjective. For example, recommendation \#46 advocates the members of the audit committee to be appointed based on their accounting background, yet without further developing which accounting background is considered as suitable. Similarly, recommendation \#53 requires that the board of directors seek to obtain an unqualified audit report. Not surprisingly, both recommendations show 100 percent level of compliance in our sample, as Table 1 shows. On the otherhand, more objective recommendations (\#47, \#48 and \#50) show the lowest levels of compliance, while recommendations \#49, \#51 and \#52 show levels of compliance above 90 percent. The average level of compliance of these recommendation is 90 percent, 59 percent of the companies complying all eight recommendations.

\footnotetext{
${ }^{2}$ Regarding core duties of transparency and disclosure in corporate governance matters, the definition and regulation of directors' duties of loyalty and diligence and the obligation of listed companies to draw up corporate governance provisions regarding the operation of their board of directors and shareholders' meetings (CNMV 2004, p. 7).
} 
The linkage between corporate governance and financial reporting quality seems rather straightforward. Weak governance structures and practices offer opportunities for managers to engage in opportunistic behaviour, eventually leading to lower accounting quality (Gonzalez and Garcia-Meca 2014). As posed by Wang (2006), the extant research has extensively documented that higher financial reporting qual- ity is associated with stronger corporate governance mechanisms. Hence, Park and Shin (2004), Rahman and Ali (2006), Patelli and Prencipe (2007) and Chen and Zhang (2014), among others, reported a significant relationship between some characteristics of the board of directors and the quality of financial statements.

Focussing specifically on the audit committee, and following our discussion in the introduction, a number of studies have investigated whether financial reporting quality has improved as a result of the requirements on the audit committee established by the SOX Act. According to DeFond and Zhang (2014) there is broad based evidence that independence and expertise of the audit committee are associated with stronger financial reporting quality (e.g., Klein 2002 and Bedard et al. 2004). In the same line, the independence and financial expertise of the audit committee exhibit a significant and negative association with the occurrence of restatements (Abbott et al. 2004) and also make the incidence of internal control problems less likely (Krishnan 2005).

As for the Spanish market, the available evidence so far does not consistently support a positive impact of the audit committee on financial reporting quality. Hence, while Sierra et al. (2012) found a negative association between the size and num- ber of meetings of the audit committee and financial reporting quality as measured by discretionary accruals, Monterrey and Sanchez (2008) did not observe any significant relationship between any characteristic of the audit committee (size, independence and number of meetings) and discretionary accruals. On the other hand, Pucheta et al. (2007) and De Andres et al. (2013) studied the impact of audit committee characteristics on the opinion of the audit report. Pucheta et al. (2007) concluded that audit committees in Spain have been only partially effective in guaranteeing higher levels of financial reporting quality and De Andres et al. (2013) 
observed that while the number of meetings of the audit committee was associated with a lower likelihood of modified opinions (higher financial reporting quality), its composition (executive/independent directors) was not.

We expect a positive and significant relationship between the level of compliance with the recommendations on the audit committee of the Unified Code (recommendations \#47 to \#52) and the quality of financial reporting. We base this expecta- tion on the fact that these recommendations aim to enforce the levels of competence and independence of the audit committee, and on prior research generally showing a positive relationship between better functioning audit committees and financial reporting quality. Accordingly, we pose the hypotheses of this research as follows:

Hypothesis 1 There is a positive and significant association between the level of compliance with recommendations on the audit committee and financial reporting quality.

In addition to hypothesis 1 which refers to the global compliance of recommendations, we also pose six additional hypotheses (1a to 1f) adressing the compliance with each specific recommendation. Hence, Hypothesis 1a states: compliance with recommendation \#47 is positively and significantly associated with financial reporting quality. ${ }^{3}$

\section{Research design and sample selection}

\subsection{Research design}

First, we present the design of the main analysis conducted with discretionaryaccruals as the proxy of financial reporting quality and afterwards the analysis with the opinion of the audit report.

\subsubsection{Discretionary accruals}

Following prior research (e.g., Myers et al. 2003), we proxy financial reporting quality with discretionary accruals. Hence, higher levels of accruals would indicate higher management discretion to manipulate earnings and, therefore, lower accounting quality. In Eq. (1) below, we show our model to compute discretionary accruals based on Jones (1991), as modified by Dechow et al. (1995):

$$
\left.T A / A_{t-1}=a_{1}\left(\nu A_{t-1}\right)+a_{2}\left(\left(\Delta R E V_{t}-\Delta R E C_{t}\right) / A_{t-1}\right)\right)+a_{3}\left(P P E / A_{t-1}\right)+E_{t}
$$

where:

\footnotetext{
$\overline{{ }^{3} \text { Hypotheses 1a, 1b, 1c, 1d, 1e and 1f refer to recommendations \# 47 }}, 48,49,50,51$ and 52 respectively.
} 


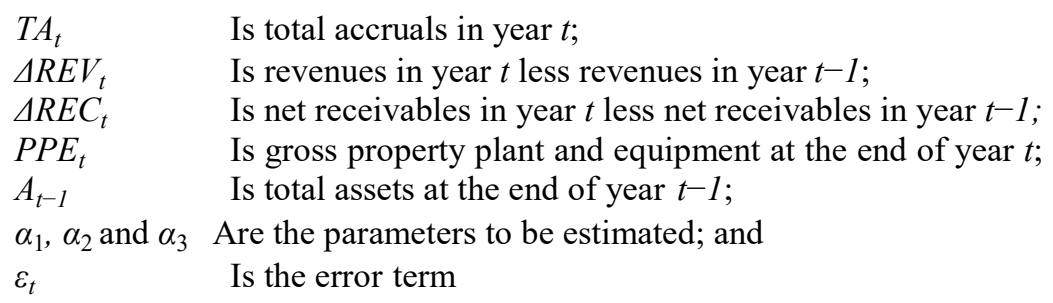

Instead of the usual cross-sectional estimations of Eq. (1) at the industry level, due to a relatively too low number of firms in some industries we follow the approach suggested by Mora and Sabater (2008) of industry-panel estimations of Eq. (1) with firm and year specific fixed effects. After obtaining discretionary accru- als from the estimation of Eq. (1), and according to the aim of this paper, we esti- mate the model given by Eq. (2) below, with the absolute value of discretionary accruals as the dependent variable. Among the independent variables, our variable of interest (COMPLIANCE) accounts for the level of compliance with the recom- mendations on the audit committee observed by the company and we also include the typical control variables used in prior related research (e.g., Myers et al. 2003, Carey and Simnett 2006 and Francis and Wang 2008).

$$
\begin{aligned}
\text { ABSDA }_{i, t}= & / 3_{0}+/ 3_{1} \text { COMPLIANCE }_{i, t-1}+/ 3_{2} \text { SIZE }_{i, t}+/ 3_{3} A G E_{i, t}+/ 3_{4} \text { LEVERAGE }_{i, t} \\
& +/ 3_{4} \text { GROWTH }_{i, t}+/ 3_{5} \text { LLOSS }_{i, t}+/ 3_{6} \text { CFFO }_{i, t}+/ 3_{7} \text { AUDFIRM }_{i, t} \\
& + \text { yIndustry dummies } \\
i, t & +8 \text { Year dummies }_{i, t}+\mu_{i, t}
\end{aligned}
$$

where,

Dependent variable

$A B S D A$ : discretionary accruals obtained as the absolute value of residuals from the estimation of Eq. (1).

Experimental variable

COMPLIANCE: the number of recommendations (from \#48 to \#52) observed by the company divided by the number of applicable recommendations. ${ }^{4}$

Control variables

SIZE: natural logarithm of total assets;

$A G E$ : natural logarithm of the number of years the client has been listed by the supervisor of the Spanish stock market;

LEVERAGE: total liabilities divided by total assets;

GROWTH: change in total assets from prior year;

LLOSS: a dichotomous variable which takes the value of 1 if the company has negative net income in the last two years and 0 otherwise;

\footnotetext{
${ }^{4}$ Although the Unified Code allows partial compliance of the recommendations, similar to other papers (e.g., Chen et al. 2007 and Sanchez et al. 2012) we only consider full compliance. Thus, partial compliance is assimilated to non-compliance.
} 
CFFO: cash flow from operations scaled over total assets;

AUDFIRM: a dichotomous variable which takes the value of 1 if the firm is audited by a Big 4 auditor and 0 otherwise.

Our variable of interest COMPLIANCE is defined as one-year lagged in the main analysis, as we expect that current accounting practices will impact next year's accounting quality. However, as the impact of compliance on financial reporting quality might also occur on a current-year basis, we also include the variable in current-year terms (COMPLIANCEc). Moreover, to assess the robustness of the results to alternative measures of this variable, we conduct additional analyses with FULLCOMPLIANCE ( 1 if the firm complies with all the recommendations and 0 otherwise) and FULLCOMPLIANCEC (FULLCOMPLIANCE in current-year terms).

Next, we justify our choice of control variables in Eq. (2). We expect larger firms (SIZE) to show higher accounting quality (e.g., Watts and Zimmerman 1986 and Myers et al. 2003). $A G E$ aims to control for differences in accruals through the life cycle (e.g., Anthony and Ramesh 1992 and Myers et al. 2003). Following Becker et al. (1998), among others, highly leveraged firms (LEVERAGE) face stronger incentives to manipulate earnings to avoid debt covenant violation. GROWTH is included because accruals are likely to be associated with growth opportunities (e.g., Johnson et al. 2002 and Carey and Simnett 2006). LLOSS accounts for a higher likelihood of earnings management by companies with losses (Carey and Simnett 2006). We include $C F F O$ because accruals and cash flows tend to be negatively correlated on average (e.g., Dechow 1994 and Sloan 1996). Finally, we expect Big 4 audit firms (AUDFIRM) to be more conservative and thus more willing to limit the use of discretionary accruals for earning management purposes (e.g., Becker et al. 1998 and Francis et al. 1999).

\subsubsection{The opinion of the audit report}

The opinion of the audit report provides another usual proxy for accounting qual- ity. External auditors play a fundamental role in the classical corporate governance scheme, as they certify the quality of financial statements. In the audit report, the external auditor, who is supposed to be both competent and independent, releases her/his opinion on the financial statements of the client. An unqualified opinion indicates that, in the auditor's view, financial statements fairly present the current situation of the firm. Conversely, modified opinion(s) in the audit report shows that the financial statements do not fully represent the current and fair situation of the firm. ${ }^{5}$ Hence, investors and any potential stakeholder of the firm can use the opinion of the audit report as an indicator of the quality of the firm's accounting information. Therefore, if, as we expect, compliance with the recommendations on the audit

\footnotetext{
${ }^{5}$ The level of disagreement of the auditor with the financial statements of the company will depend on the number and importance of the modified opinions.
} 
committee is positively and significantly associated with financial reporting quality, the likelihood of a modified opinion should be lower for these companies.. ${ }^{6}$

Similar to prior studies (e.g., Chi and Chin 2011) we consider audit reports with either qualified, unfavourable, disclaimer of opinion, or with explanatory paragraphs expressing doubts about the future of the company, collectively as qualified reports. To test the relationship between compliance with recommendations and the opinion of the audit report, we propose the logistic model given by Eq. (3) below, with $M A O$ (defined as 1 if the client receives a qualified audit report and 0 otherwise) as the dependent variable, our variable of interest COMPLIANCE and the usual control variables.

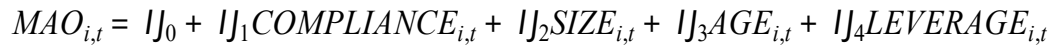

$$
\begin{aligned}
& +I_{6} L_{L O S S_{i, t}}+I_{7} A U D F I R M_{i, t}+1 J_{8} Z M I J W_{i, t}+1 J_{9} C A C L_{i, t t} \\
& +\quad \text { Industry dummies }_{i, t}+\text { ). Year dummies } \text { dum }_{i, t}+\mathrm{B}_{i, t}
\end{aligned}
$$

Control variables in Eq. (3) attempt to capture the main determinants of the auditor's opinion, and are basically related to the risk of litigation faced by the auditor when auditing a client. In addition to the control variables already used in the analysis conducted with discretionary accruals ${ }^{7}$ (SIZE, AGE, LEVERAGE, LLOSS and AUDFIRM), we also include ZMIJW (the adjusted Zmijewski's 1984 score) and $C A C L$ (current assets over current liabilities).

Next, we discuss the control variables in Eq. (3). The size of the client might affect the auditor's propensity to issue a modified audit opinion. First, as the higher risk of litigation associated with large clients (Lys and Watts 1994; Shu 2000) could make auditors more willing to issue a modified opinion. However, large companies have also more negotiating power with the audit firm to avoid a qualified report. Therefore, we do not predict the sign of the coefficient of SIZE. AGE accounts for the higher likelihood of financial distress (and litigation risk for the audit firm) of companies with a short listing history (Dopuch et al. 1987; Chi and Chin 2011). As in Carey and Simnett (2006), among others, AUDFIRM intends to capture the higher propensity of Big 4 auditors to issue modified audit opinions. The remaining variables (LEVERAGE, ZMIJW, LLOSS and CACL) are indicators of financial health which account for the litigation risk of the auditor. Hence, higher financial lever- age (LEVERAGE) makes bankruptcy more likely and consequently raises litigation risk. The Zmijewski score (ZMIJW) is a usual proxy of the probability of bankruptcy (Krishnan and Krishnan 1997; Carey and Simnett 2006). Following Chi and Chin (2011), we include LLOSS to complement ZMIJW, which accounts only for the current period, while LLOSS is used to indicate companies with a two-year trend of

\footnotetext{
${ }^{6}$ While a modified opinion in the audit report provides a clear indicator of poor accounting quality, at the same time it might also provide an indicator of high audit quality, as it can be interpreted as a prove of auditor independence.

${ }^{7}$ However, we include neither GROWTH nor $C F F O$, as both variables are expected to be associated with the level of discretionary accruals but not with the opinion of the audit report.
} 
negative earnings. Previous studies have shown that firms with losses face higher probabilities of modified audit opinions (Dopuch et al. 1987). Conversely, higher levels of liquidity $(C A C L)$ should make modified opinions less likely. Therefore, we expect positive coefficients for LEVERAGE, ZMIJW and LLOSS and negative coefficient for $C A C L$.

\subsection{Sample selection}

Our sample consists of non-financial companies listed in the Spanish Stock Exchange (Sistema de Interconexión Bursátil Español) for the years between 2007 and 2013. The election of the research period is due to the fact that 2007 is the first year for which we have declarations of compliance with the recommendations of the Unified Code. On the other hand, 2012 was the last year covered by the CNMV reports on the level of compliance of the Unified Code. Therefore, we are able to compute the experimental variable COMPLIANCE for each year of the 2007-2012 period. Since in the main analysis the experimental variable is defined as one-year lagged, all the variables in Eqs. (2) and (3) refer to the years between 2008 and 2013, with the exception of COMPLIANCE which refers to the years between 2007 and 2012. In the estimation with current-year compliance (COMPLIANCEc) all var- iables refer to the years between 2008 and 2012.

The sample initially consisted of 101 firms and, given the six-year research period, of a maximum of 606 firm-year observations. However, due of lack of data, in the analysis conducted with discretionary accruals we lost 52 observations, and 64 firmyear observations in the analysis with the opinion of the audit report. Hence, the final sample consists of 554 firm-year observations in the model with discretion- ary accruals and of 542 in the model with the opinion of the audit report. Moreo- ver, in the estimation with compliance in current-year terms we lost all the observa- tions for the year 2007, and therefore the analyses with discretionary accruals and the opinion of the audit report are estimated with samples of 466 and 462 firm-year observations, respectively.

Table 2 shows some descriptive statistics for the independent variables in Eqs. (2) and (3). The most interesting point has to do with the experimental vari- able COMPLIANCE, which shows an average of 0.9 (90 percent of compliance with the accounting recommendations) with a minimum of 0.37 . Results also show an extreme level of concentration (91 percent) of the Spanish audit market by Big-4 firms.

Table 3 displays Pearson correlation coefficients between each pair of variables in Eq. (2). The correlation pattern for the dependent variable ( $A B S D A)$ strongly meets our expectations. Hence, discretionary accruals are positively and significantly correlated with $L E V E R A G E$, GROWTH and LLOSS and negatively and significantly correlated with SIZE, $A G E, C F F O$ and $A U D F I R M$. However, we do not observe any significant relationship with our variable of interest COMPLIANCE. Thus, according with Table 3, higher compliance of does not seem to be associated with higher accounting quality. The Table reveals some other interesting features, such as the positive and significant correlation between COMPLIANCE and AUDFIRM, which indicates higher levels of compliance for those firms audited by Big-4 auditors or the fact that larger firms generally show higher compliance. The relatively low 
correlations for each pair of independent variables (the maximum value is 0.35 ) do not suggest multicollinearity problems in the data. However, after the estimation of Eq. (2) we compute variance inflation factors. The relatively low values of these factors (mean value of 1.23 , with a maximum of 1.43 for LLOSS) support or view that multicollinearity should not seriously affect our results.

\section{Empirical results}

\subsection{Discretionary accruals}

Before the estimation of Eq. (2) we conduct a preliminary univariate analysis to assess the relationship between compliance with recommendations and discretionary accruals. First, we differentiate between firms which comply with all recommendations and the rest, and then we carry out a similar analysis for each specific recommendation. After defining the different subsamples, we compute mean and median values of discretionary accruals across subsamples and conduct both the $t$ test of differences of means and the Mann-Whitney test of differences of medians to assess about the statistical significance of these differences. Table 4 summarizes the results of the univariate analysis. The main result is that firms that comply with all recommendations present significantly lower mean and median discretionary accruals. When recommendations are individually taken, we observe significance with both the $t$-test and Mann-Witney test for recommendations \#48 and \#50, while for recommendation \#47 significance is reported only for median accruals. In all cases the sign of these differences is as predicted, discretionary accruals being smaller for those firms complying with the recommendation. Therefore, the results of the univariate analysis suggest a positive and significant relationship between compliance and financial reporting quality.

After the preliminary univariate analysis, Table 5 displays the results of the four estimations of Eq. (2). Columns A and B shows the estimates of the models with oneyear lagged compliance (COMPLIANCE) and current-year compliance (COMPLIANCEC), respectively. Then, columns $\mathrm{C}$ and $\mathrm{D}$ show the results with the dichotomous versions of compliance (FULLCOMPLIANCE in column C and FULLCOMPLIANCEC in column D). In keeping with the panel structure of the dataset, we use panel data models for the estimations. As the modified Wald test confirms the expected heteroscedasticity in the data and we also observe significant correlation in the error term, estimations are performed with generalized least squares correcting for heteroscedasticity and correlation. Moreover, to avoid the negative effects of outliers, all continuous variables are winsorized to the top and bottom one percent. All four estimations are globally significant at the usual levels $(P$-value $<0.00)$.

The most interesting result in Table 5 is the negative and significant coefficients of our variable of interest, in all the estimations (COMPLIANCE, COMPLIANCEC, FULLCOMPLIANCE and FULLCOMPLIANCEC). Hence, results provide sound and consistent support for a negative relationship between the level of compli- ance with the recommendations on the audit committee of the Unified Code and 
discretionary accruals, and therefore, support Hypothesis 1 which states thatcompliance will be positively and significantly associated with financial reporting quality. Additionally, the results of the multivariate analysis are consistent with the univariate analysis displayed in Table 4 which had already anticipated a direct relationship between compliance and financial reporting quality.

Given that the recommendations examined here are focused on the functioning of the audit committee, our results indicate that companies with better functioning audit committees present higher accounting quality. It should be noted that, unlike international evidence which generally agrees on a relevant role of the audit committee (e.g., Abbott and Parker 2000 and Bedard et al. 2004), prior evidence for Spain had been rather mixed. Hence, while Sierra et al. (2012) concluded that bet- ter functioning audit committees were associated with lower discretionary accruals, Monterrey and Sanchez (2008) did not reported significant results. Therefore, our results would be more in line with the international evidence than with prior studies for Spain.

As for the control variables, we report significant results for most of them (SIZE, $A G E, L E V E R A G E, L L O S S, C F F O$ and AUDFIRM). With the only exception of $C F F O$, in all these cases the sign of the coefficient is as predicted. Hence, we observe lower discretionary accruals (higher financial reporting quality) for larger $(S I Z E)$ and well-established firms $(A G E)$, and also for firms with Big 4 auditors $(A U D F I R M)$. Also meeting our expectations, high levels of financial leverage ( $L E V-E R A G E)$ or losses (LLOSS) are also associated with higher levels of discretionary accruals (lower financial reporting quality). We have performed two robustness checks. First, we reestimate Eq. (2) with the signed value of discretionary accruals instead of the absolute value as the dependent variable. We used the absolute value of discretionary accruals to make our results more comparable with prior related studies, particularly with those conducted with samples of Spanish companies (Monterrey and Sanchez 2008 and Sierra et al. 2012). However, in the estimations conducted with signed discretionary accruals, we do not observe any significant relationship between compliance with recom- mendations and financial reporting quality (results not reported). Secondly, Trom- betta and Imperatore (2014) argued that the dynamic of financial crises might lead non-monotonic effects on earnings quality. Hence, earnings management decreases when the intensity of the crisis is low, while it increases when the crisis is acute. As our research period includes the years of the recent economic downturn in Spain, we have considered important to control for this fact. Accordingly, we reestimate Eq. (2) with the new variable CRISIS, defined as 1 for the years 2009, 2010 and 2012 (the worst years of the crisis) and 0 otherwise, substituting the year controls. Results (not reported) are qualitatively the same as those in Table 5.

Next, we present and discuss the results of the analysis conducted at the level of individual recommendations. We defined six dichotomous variables (one for each of the following recommendations: \#47, \#48, \#49, \#50, \#51 and \#52) indicating compliance or not with each recommendation. Next, we perform sequential estimations 
of Eq. (2), one for each new variable. Results of the new estimations, in Table 6 are consistent with those in Table 5 supporting a positive and significant relationship between compliance with recommendations and financial reporting quality. Hence, we report significant results for recommendations \#47 (listed companies should have an internal audit function, under the supervision of the audit committee), \#48 (the head of internal audit should present an annual work program to the audit committee) and $\# 50$ (on the specific functions of the audit committee). In all three cases, the sign of the coefficient is negative as predicted. Therefore, compliance with each of these specific recommendations is associated with lower levels of discretionary accruals (higher financial reporting quality). Conversely, we do not report significant results for recommendations \#49 (about control and risk management policy), \#51 (the audit committee should be empowered to meet with any company employee or manager) or \#52 (on the reporting of the audit committee on various points). Summing up, results provide support for Hypotheses $1 \mathrm{a}, 1 \mathrm{~b}$ and $1 \mathrm{~d}$. It should be noted however, that recommendations \#49, \#51 and \#52 show the highest levels of compliance in our sample, in all cases above 90 percent. Therefore, the low variability of the experimental variables in these cases might have likely contributed to explain the lack of significant effects for these variables.

\subsection{The opinion of the audit report}

We estimate Eq. (3) with a panel data logistic model with random effects. Results are shown in Table 7. The log-likelihood ratio test (not reported) advocates the use of a panel data approach over the alternative pooled logistic estimations. Moreo- ver, all four estimations in Table 7 are globally significant at the usual levels $(P$-value $<0.00)$. The main result is the negative and statistically significant coef- ficients of the variable of interest in all four estimations. Hence, compliance is negatively and significantly associated with the likelihood of a modified opinion in the audit report, and therefore, positively and significantly associated with finan- cial reporting quality. As in the analysis conducted with discretionary accruals, the fact that the same result holds independently on how the experimental variable in introduced in the model (in current or lagged terms or as a continuous or discrete variable) offers a proof of robustness. Accordingly, similar to the analysis con- ducted with discretionary accruals, these results provide consistent support for our Hypothesis 1 of a positive and significant relationship between compliance with the accounting recommendations and financial reporting quality.

Results for control variables strongly meet our expectations, as whenever a significant result is observed it is always in the predicted direction. Hence, modified opinions are strongly associated with the firm's financial condition. We report significant results for financial leverage (LEVERAGE), the reporting of losses (LLOSS), the probability of bankruptcy $(Z M I J W)$ and the level of liquidity $(C A C L)$. We also observe that a modified opinion is less likely for large than for small firms. We had not predicted the sign of the coefficient of SIZE, as larger firms involve higher risk of litigation for the auditor (and consequently higher likelihood of a qualified opin- ion), though these firms also have more negotiating power to avoid an audit qualifi- cation in the audit report.

We have also addressed the relationship between compliance with each specific 
recommendation and the likelihood of a modified opinion. The results of the new set of estimations of Eq. (3) with the experimental variables REC47, REC48, REC49, REC50, REC51 and REC52 are shown in Table 8. All six estimations are globally significant at the usual levels $(P$-value $<0.00)$. We observe significant results for the variables $R E C 47$ and REC48 ( $P$-value $<0.10)$, in both cases with the predicted negative sign. Moreover, for REC50 results are on the edge of marginal significance. These results are rather consistent with those in Table 6, which also displayed significant coefficients for REC47, REC48 and REC50 and support the main conclusion in Table 7 of a significant relationship between compliance with the code and the opinion of the audit report.

\section{Concluding remarks}

With the aim of enhancing financial reporting quality, the SOX Act in the US and similar regulations in other countries mandated changes in the audit committee. Numerous studies since then have investigated whether these requirements have been effective. However, in addition to this "hard" legislation approach to corporate governance, regulators have also adopted a "soft" approach based on codes of good practices. Some of the recommendations of these codes refer to the audit committee. We extend the literature on the effectiveness of the audit committee by investigating the relationship between compliance with recommendations on the audit committee and financial reporting quality.

The main result of this research is that there exists a strong and positive relationship between the level of compliance with the recommendations on the audit committee of the Spanish Unified Code and the quality of financial reporting. This result seems robust as it holds across various checks. Additionally, results observed at the level of individual recommendations support the main conclusion that compliance is associated with higher financial reporting quality. Therefore, while extant evidence for Spain does not consistently support the view that the audit committee plays a significant role in guaranteeing financial reporting quality, the results we report aremore in line with international evidence. Given the generally high levels of compli- ance in our sample, the likelihood of reporting significant results for our variables of interest was relatively low. Thus, the fact that we report a strong and consistent rela- tionship between compliance and financial reporting quality in such a context can be taken as another proof of the robustness of the results.

There is an open debate about the pros and cons of the different regulatory approaches to corporate governance. Some authors have questioned the very effectiveness of codes of good practices, based on the "comply or explain" principle, to effectively enhance corporate governance structures and practices. This study contributes to the debate. According to our results, codes of good practices might be a suitable tool in order to strengthen governance structures and practices. At a more practical level and focusing specifically on the accounting and auditing fields, results might have some interesting implications, as investors, market participants and, in general, any potential user of financial reports can take the level of compliance with recommendations as a feasible and reliable indicator of the quality of the accounting information released by the company.

This research might be extended in several ways. First, by examining the relation- 
ship between compliance with recommendations other than those affecting the audit committee of codes of good practices and financial reporting quality. Secondly, it would also be interesting to address the relationship between compliance with recommendations (not only with recommendations on the audit committee) and more general indicators of governance, such as different metrics of performance.

\section{Appendix. Recommendations of accounting content (\# 46-53) in the Spanish Unified Code (CNMV 2006)}

46. All members of the Audit Committee, particularly its chairman, should be appointed with regard to their knowledge and background in accounting, auditing and risk management matters.

47. Listed companies should have an internal audit function, under the supervision of the Audit Committee, to ensure the proper operation of internal reporting and control systems.

48. The head of internal audit should present an annual work program to the Audit Committee; report to it directly on any incidents arising during its implementation; and submit an activities report at the end of the year.

49. Control and risk management policy shall specify at least:

(a) The different types of risk (operational, technological, financial, legal, reputational...) the company is exposed to, with the inclusion under financial or economic risks of contingent liabilities and other off-balance-sheet risks;

(b) The determination of the risk level the company sees as acceptable;

(c) Measures in place to mitigate the impact of risk events should they occur;

50. The internal reporting and control systems to be used to control and manage the above risks, including contingent liabilities and off-balance-sheet risks. The Audit Committee's role will be:

1. With respect to internal control and reporting systems:

(a) Monitor the preparation and the integrity of the financial information prepared on the company and, where appropriate, the group, checking for compliance with legal provisions and the correct application of accounting principles.

(b) Review internal control and risk management systems on a regular basis, so main risks are properly identified, managed and disclosed.

(c) Oversee the independence and effectiveness of the internal audit function; propose the selection, appointment, reappointment and removal of the head of internal audit; propose the resources to be assigned to the internal audit function; receive regular report backs on its activities; and verify that senior management are acting on the conclusions and recommendations of its reports.

(d) Establish and supervise a mechanism whereby staff can report any irregularities they detect in the course of their work anonymously or confiden- 
tially.

2. With respect to the external auditor:

(a) Make recommendations to the Board for the selection, appointment, reappointment and removal of the external auditor, and the terms and conditions of his engagement.

(b) Receive regular information from the external auditor on the progress and findings of the audit program, and check that senior management are acting on its recommendations.

(c) Oversee the independence of the external auditor, to which end: (i) The company will notify any change of auditor to the CNMV as a significant event, stating the reasons for its decision. (ii) The Committee will ensure that the company and the auditor adhere to current regulations on the provision of non-audit services, the limits on the concentration of the auditor's business and, in general, other requirements designed to safeguard auditors' independence; iii) The Committee should investigate the issues giving rise to the resignation of any external auditor.

(d) In case of groups, the Committee should urge the group auditor to take on the auditing of all component companies.

51. The Audit Committee should be empowered to meet with any company employee or manager, even ordering their appearance without the presence of another senior officer.

(a) The Audit Committee will report on the following points from Recommendation 8 before Board decision-making:The financial information that listed companies must periodically disclose. The Committee shall ensure that intermediate statements are drawn up under the same accounting principles as the annual statements and, to this end, may ask the external auditor to conduct a limited review.

(b) The creation or acquisition of shares in special purpose vehicles or entities resident in countries or territories considered tax havens, and any other transactions or operations of a comparable nature whose complexity might impair the transparency of the group.

(c) Related-party transactions, except where their scrutiny has been entrusted to some other supervision and control committee.

52. The Board of Directors shall seek to present the annual accounts to the Gen- eral Shareholders' Meeting without reservations or qualifications in the audit report. Should such reservations or qualifications exist, both the Chairman of the Audit Committee and the auditors should give a clear account to shareholders of their scope and content.

\section{References}

Abbott, L. J., \& Parker, S. (2000). Auditor selection and audit committee characteristics. Auditing: A 
Journal of Practice \& Theory, 19(2), 47-66.

Abbott, L. J., Parker, S., \& Peters, G. F. (2004). Audit committee characteristics and restatements. Auditing: A Journal of Practice \& Theory, 23(1), 69-87.

Aguilera, R. V., \& Cuervo-Cazurra, A. (2009). Codes of good governance. Corporate Governance: An International Review, 17(3), 376-387.

Anthony, J. H., \& Ramesh, K. (1992). Association between accounting performance measures and stock prices: A test of the life cycle hypothesis. Journal of Accounting and Economics, 15(2-3), 203-227.

Becker, C. L., DeFond, M. L., Jiambalvo, J., \& Subramanyam, K. R. (1998). The effect of audit quality on earnings management. Contemporary Accounting Research, 15(1), 1-24.

Bedard, J., Chtourou, S. M., \& Courteau, L. (2004). The effect of audit committee expertise, independence. Auditing: A Journal of Practice and Theory, 23(2), 13-35.

Carey, P. J., \& Simnett, R. (2006). Audit partner tenure and audit quality. The Accounting Review, 81(3), 653-676.

Chen, A., Tsao, M., \& Wu, C. (2007). Building a corporate governance index from the perspectives of ownership and leadership for firms in Taiwan. Corporate Governance: An International Review, $15(2), 251-261$

Chen, J. J., \& Zhang, H. (2014). The impact of the corporate governance code on earnings managementEvidence from Chinese listed companies. European Financial Management, 20(3), 596-632.

Chi, H. Y., \& Chin, C. L. (2011). Firm versus partner measures of auditor industry expertise and effects on auditor quality. Auditing: A Journal of Practice and Theory, 30(2), 201-229.

CNMV. (2004). Corporate governance report of entities with securities admitted to trading on official secondary markets. Madrid: Comisión Nacional del Mercado de Valores.

CNMV. (2006). Good governance code of listed companies. Madrid: Comisión Nacional del Mercado de Valores.

CNMV. (2012). Informe anual de la CNMV sobre los mercados de valores y su actuación. Ejercicio 2012. Comisión Nacional del Mercado de Valores, Madrid.

CNMV. (2015). Good governance code of listed companies. Madrid: Comisión Nacional del Mercado de Valores.

De Andres Suarez, J., Garcia, E. C., Mendez, C. F., \& Gutierrez, C. R. (2013). The effectiveness of the audit committee in Spain: implications of its existence on the auditor's opinion. SERIEs, 4(3), 333352. 
De Vlaminck, N., \& Sarens, G. (2015). The relationship between audit committee characteristics and financial statement quality: evidence from Belgium. Journal of Management and Governance, 19(1), $145-166$.

Dechow, P. M. (1994). Accounting earnings and cash flows as measures of firm performance: The role of accounting accruals. Journal of Accounting and Economics, 18(1), 3-42.

Dechow, P. M., Sloan, R. G., \& Sweeny, A. P. (1995). Detecting earnings management. The Accounting Review, 70(2), 193-226.

DeFond, M., \& Zhang, J. (2014). A review of archival auditing research. Journal of Accounting and Economics, 58(2), 275-326.

Dopuch, N., Holthausen, R. W., \& Leftwich, R. W. (1987). Predicting audit qualifications with financial and market variables. The Accounting Review, 62(3), 431-454.

Francis, J. R., Maydew, E. L., \& Sparks, H. C. (1999). The role of Big 6 auditors in the credible reporting of accruals. Auditing: A Journal of Practice \& Theory, 18(2), 17-34.

Francis, J. R., \& Wang, D. (2008). The joint effect of investor protection and Big 4 audits on earnings quality around the world. Contemporary Accounting Research, 25(1), 157-191.

Gonzalez, J. S., \& Garcia-Meca, E. (2014). Does corporate governance influence earnings management in Latin American markets? Journal of Business Ethics, 121(3), 419-440.

Johnson, V. E., Khurana, I., \& Reynolds, J. K. (2002). Audit firm tenure and the quality of financial reports. Contemporary Accounting Research, 19(4), 637-660.

Jones, J. (1991). Earnings management during import relief investigations. Journal of Accounting Research, 29(2), 193-228.

Klein, A. (2002). Audit committee, board of director characteristics, and earnings management. Journal of Accounting and Economics, 33(3), 375-400.

Krishnan, J. (2005). Audit committee quality and internal control: An empirical analysis. The Accounting Review, 80(2), 649-675.

Krishnan, J., \& Krishnan, J. (1997). Litigation risk and auditor resignations. The Accounting Review, 72(4), 539-560.

Lys, T., \& Watts, R. L. (1994). Lawsuits against auditors. Journal of Accounting Research, 32(supplement), 65-93.

Monterrey, J., \& Sanchez, A. (2008). Gobierno corporativo y calidad de la información contable: evidencia empírica española. Spanish Accounting Review, 11(1), 65-98.

Mora, A., \& Sabater, A. (2008). Evidence of income-decreasing earnings management before labour negotiations within firms. Investigaciones Económicas, 32(2), 201-230.

Myers, J. N., Myers, L. A., \& Omer, T. C. (2003). Exploring the term of the auditor-client relationship and the quality of earnings: A case for mandatory auditor rotation? The Accounting Review, 78(3), 779 799.

Park, Y. W., \& Shin, H. H. (2004). Board composition and earnings management in Canada. Journal of Corporate Finance, 10(3), 431-457.

Patelli, L., \& Prencipe, A. (2007). The relationship between voluntary disclosure and independent directors in the presence of a dominant shareholder. European Accounting Review, 16(1), 5-33.

Pucheta-Martínez, M. C., \& De Fuentes, C. (2007). The impact of audit committee characteristics on the enhancement of the quality of financial reporting: An empirical study in the Spanish context. Corporate Governance: An International Review, 15(6), 1394-1412.

Rahman, R., \& Ali, F. (2006). Board, audit committee, culture and earnings management: Malaysian evidence. Managerial Auditing Journal, 21(7), 783-804.

Rodriguez-Fernandez, M. (2016). Social responsibility and financial performance: The role of good corporate governance. BRQ Business Research Quarterly, 19(2), 137-151.

Sanchez, P. C., Ballesta, J. P. S., \& Garcia-Meca, E. (2012). Factores explicativos del buen gobierno en la empresa española. Spanish Accounting Review, 15(2), 237-255.

Shu, S. (2000). Auditor resignations: clientele effects and legal liability. Journal of Accounting and Economics, 29(2), 173-205.

Sierra, L., Ruiz-Barbadillo, E., \& Orta, M. (2012). Audit committee and internal audit and the quality of earnings: empirical evidence from Spanish companies. Journal of Management and Governance, 16(2), 305-331.

Sloan, R. (1996). Do stock prices fully reflect information in accruals and cash flows about future earnings? The Accounting Review, 71(3), 289-315.

Trombetta, M., \& Imperatore, C. (2014). The dynamic of financial crises and its non-monotonic effects on earnings quality. Journal of Accounting and Public Policy, 33(3), 205-232. 
Wang, D. (2006). Founding family ownership and earnings quality. Journal of Accounting Research, 44(3), 619-656.

Watts, R. L., \& Zimmerman, J. L. (1986). Positive accounting theory. Englewood: Prentice-Hall Inc. Weil,

G. \& Manges L. (2002). Comparative study of corporate governance codes relevant to the European Union and its member states, on behalf of the European Commission. Internal Market Directorate General.

Zmijewski, M. E. (1984). Methodological issues related to the estimation of financial distress prediction models. Journal of Accounting Research, 22(supplement), 59-82. 

Table 1 Level of compliance

with the accounting

recommendations of the

Spanish Unified Code in our

sample (years 2007-12)

Recommendation \#

Compliance $(\%)$

46

100

85

$48 \quad 81$

$49+94$

$50-73$

$51-96$

$52-91$

$53-100$

All recommendations $\quad 59$ 
Table 2 Descriptive statistics for the independent variables

\begin{tabular}{lrrrrr}
\multicolumn{1}{r}{ Variable } & Mean & Median & SDMinimum & Maximum \\
\hline SIZE & 6.84 & 6.66 & 1.77 & 3.42 & 11.51 \\
AGE (in years) & 16.47 & 19 & 7.09 & 2.00 & 27.00 \\
LEVERAGE & 0.67 & 0.66 & 0.24 & 0.14 & 1.72 \\
GROWTH & 1.16 & 1.05 & 0.78 & 0.29 & 7.53 \\
LLOSS & 0.21 & 0.00 & 0.41 & 0.00 & 1.00 \\
CFFO & 0.06 & 0.06 & 0.10 & -0.29 & 0.38 \\
AUDFIRM & 0.91 & 1.00 & 0.29 & 0.00 & 1.00 \\
ZMIJW & -2.07 & -1.98 & 1.60 & -5.92 & 1.16 \\
CACL & 1.44 & 1.18 & 1.28 & 0.08 & 20.00 \\
COMPLIANCE & 0.90 & 1.00 & 0.15 & 0.37 & 1.00 \\
\hline
\end{tabular}

SIZE natural logarithm of total assets, $A G E$ number of years the client has been listed in the Spanish stock market, LEVERAGE total liabilities divided by total assets, GROWTH: change in total assets from prior year, LLOSS 1 if the company has negative net income in the last two years and 0 otherwise, $C F F O$ cash flow from operations scaled over total assets, AUDFIRM 1 if the audit firm is a Big 4 auditor and 0 otherwise, $Z M I J W$ the probability of bankruptcy, $C A C L$ current assets divided by current liabilities, COMPLIANCE number of accounting recommendations observed by the company in year $t-1$ divided by the number of applicable recommendations 
Table 3 Pearson correlations and levels of significance between pairs of variables in the analysis conducted with discretionary accruals

\begin{tabular}{|c|c|c|c|c|c|c|c|c|}
\hline & $A B S D A$ & $S I Z E$ & $A G E$ & LEVER- & GROWTH & LLOSS & $\mathrm{CFFO}$ & $A U D F I R M$ \\
\hline & & & & $A G E$ & & & & \\
\hline SIZE & $-0.14 * * *$ & & & & & & & \\
\hline$A G E$ & $-0.14 * * *$ & $0.13 * * *$ & & & & & & \\
\hline $\begin{array}{c}\text { LEVER- } \\
A G E\end{array}$ & $0.11 * * *$ & $0.26 * * *$ & 0.02 & & & & & \\
\hline GROWTH & $0.33 * * *$ & -0.04 & $-0.20 * * *$ & -0.03 & & & & \\
\hline LLOSS & $0.08 * *$ & $-012 * * *$ & -0.00 & $0.34 * * *$ & $-0.14 * * *$ & & & \\
\hline CFFO & $-0.25 * * *$ & $0.12 * * *$ & -0.04 & $-0.14 * * *$ & $-0.07 * *$ & $-0.26 * * *$ & & \\
\hline AUDFIRM & $-0.23 * * *$ & $0.20 * * *$ & -0.05 & $-0.14 * * *$ & $-0.10^{* * *}$ & $-0.15^{* * *}$ & $0.14 * * *$ & \\
\hline $\begin{array}{c}\text { COMPLI- } \\
\text { ANCE }\end{array}$ & -0.07 & $0.35^{* * *}$ & $-0.10^{* *}$ & $0.12 * * *$ & -0.02 & -0.04 & $0.10^{* *}$ & $0.11 * * *$ \\
\hline
\end{tabular}

$A B S D A$ discretionary accruals in absolute values, SIZE: natural logarithm of total assets, $A G E$ natural logarithm of the number of years the client has been listed in the Spanish stock market, LEVERAGE total liabilities divided by total assets, GROWTH change in total assets from prior year, LLOSS 1 if the company has negative net income in the last two years and 0 otherwise, $C F F O$ cash flow from operations scaled over total assets, AUDFIRM 1 if the audit firm is a Big 4 auditor and 0 otherwise, COMPLIANCE number of accounting recommendations observed by the company in year $t-1$ divided by the number of applicable recommendations

$*, * *, * * *$ Significant at 10 percent, five percent and one percent levels, respectively 
Table 4 Univariate analysis of differences of mean and median discretionary accruals by categories of compliance with accounting recommendations
Mean Sign. Median Sign.

\begin{tabular}{llllll}
\hline Full Compliance & Yes & 0.051 & $* *$ & 0.032 & $* * *$ \\
& No & 0.063 & & 0.043 & \\
$\operatorname{Rec} 47$ & Yes & 0.055 & & 0.033 & $* * *$ \\
& No & 0.069 & & 0.054 & \\
$\operatorname{Rec} 48$ & Yes & 0.055 & $* *$ & 0.032 & $* * *$ \\
& No & 0.068 & & 0.053 & \\
$\operatorname{Rec} 49$ & Yes & 0.057 & & 0.036 & \\
& No & 0.069 & & 0.033 & \\
$\operatorname{Rec} 50$ & Yes & 0.052 & $*$ & 0.032 & $* * *$ \\
& No & 0.074 & & 0.049 & \\
$\operatorname{Rec51}$ & Yes & 0.044 & & 0.035 & \\
& No & 0.058 & & 0.040 & \\
$\operatorname{Rec} 52$ & Yes & 0.055 & & 0.034 & \\
& No & 0.080 & & 0.049 &
\end{tabular}

The $t$-test (Mann-Whitney test) is used for assessing the significance of mean (median) accruals

Full Compliance compliance with all the accounting recommendations (from \#47 to \#52), Rec47 compliance with recommendation \#47, Rec48 compliance with recommendation \#48, Rec49 compliance with recommendation \#49, Rec50 compliance with recommendation \#50, Rec51 compliance with recommendation \#51, Rec52: compliance with recommendation \#52

$*, * *, * *$ Significant at 10 percent, five percent and one percent levels, respectively 
Table 5 Results of the multivariate analysis (I). The relationship between the level of compliance with accounting recommendations and discretionary accruals

\begin{tabular}{|c|c|c|c|c|c|}
\hline Variable & Predicted sign & Column A & Column B & Column C & Column D \\
\hline COMPLIANCE & -(Hypothesis) & $\begin{array}{l}-0.028 \\
(-3.23) * * *\end{array}$ & & & \\
\hline COMPLIANCEC & -(Hypothesis) & & $\begin{array}{l}-0.042 \\
\quad(-4.05)^{* * * *}\end{array}$ & & \\
\hline $\begin{array}{l}\text { FULLCOMPLI- } \\
\quad \text { ANCE }\end{array}$ & -(Hypothesis) & & & $\begin{array}{l}-0.007 \\
(-2.37)^{* *}\end{array}$ & \\
\hline $\begin{array}{l}\text { FULLCOMPLI- } \\
\quad A N C E C\end{array}$ & -(Hypothesis) & & & & $\begin{array}{l}-0.007 \\
(-3.68) * * *\end{array}$ \\
\hline$S I Z E$ & - & $\begin{array}{l}-0.004 \\
(-4.23)^{* * *}\end{array}$ & $\begin{array}{l}-0.003 \\
(-2.56)^{* * *}\end{array}$ & $\begin{array}{l}-0.004 \\
(-4.28)^{* * *}\end{array}$ & $\begin{array}{l}-0.003 \\
(-3.07)^{* * *}\end{array}$ \\
\hline$A G E$ & - & $\begin{array}{l}-0.007 \\
(-2.00) * *\end{array}$ & $\begin{array}{l}-0.015 \\
(-3.85) * * *\end{array}$ & $\begin{array}{l}-0.006 \\
(-1.60)\end{array}$ & $\begin{array}{l}-0.013 \\
(-3.44) * * *\end{array}$ \\
\hline$L E V E R A G E$ & + & $\begin{array}{l}0.061 \\
(6.42)^{* * *}\end{array}$ & $\begin{array}{l}0.027 \\
(2.55)^{* *}\end{array}$ & $\begin{array}{l}0.062 \\
(6.44)^{* * *}\end{array}$ & $\begin{array}{l}0.025 \\
(2.41)^{* *}\end{array}$ \\
\hline GROWTH & + & $\begin{array}{l}0.006 \\
(1.19)\end{array}$ & $\begin{array}{l}0.008 \\
(1.58)\end{array}$ & $\begin{array}{l}0.007 \\
(1.34)\end{array}$ & $\begin{array}{l}0.008 \\
(1.53)\end{array}$ \\
\hline LLOSS & + & $\begin{array}{l}0.016 \\
(3.95)^{* * *}\end{array}$ & $\begin{array}{l}0.009 \\
(2.11)^{* *}\end{array}$ & $\begin{array}{l}0.017 \\
(4.08)^{* * * *}\end{array}$ & $\begin{array}{l}0.010 \\
(2.30)^{* *}\end{array}$ \\
\hline$C F F O$ & - & $\begin{array}{l}0.064 \\
(3.68)^{* * *}\end{array}$ & $\begin{array}{l}0.049 \\
(2.39)^{* *}\end{array}$ & $\begin{array}{l}0.084 \\
(3.80)^{* * *}\end{array}$ & $\begin{array}{l}0.048 \\
(2.24)^{* *}\end{array}$ \\
\hline$A U D F I R M$ & - & $\begin{array}{l}-0.023(- \\
2.42)^{* *}\end{array}$ & $\begin{array}{l}-0.027 \\
(-4.02) * * *\end{array}$ & $\begin{array}{l}-0.022 \\
(-2.36)^{* *}\end{array}$ & $\begin{array}{l}-0.025 \\
(-3.81) * * *\end{array}$ \\
\hline YEAR controls & & Yes & Yes & Yes & Yes \\
\hline $\begin{array}{l}\text { INDUSTRY con- } \\
\quad \text { trols }\end{array}$ & & Yes & Yes & Yes & Yes \\
\hline Constant & & $0.137(6.38)^{* * *}$ & $\begin{array}{l}0.182 \\
(7.95)^{* * *}\end{array}$ & $\begin{array}{l}0.109 \\
(5.40)^{* * *}\end{array}$ & $\begin{array}{l}0.144 \\
(6.84)^{* * *}\end{array}$ \\
\hline $\begin{array}{l}\text { \# of observations } \\
\text { Pseudo } \mathrm{R}^{2} \\
\text { Wald Chi (2) }\end{array}$ & & $\begin{array}{l}554 \\
0.19 \\
169.19^{* * *}\end{array}$ & $\begin{array}{l}466 \\
0.16 \\
127.80 * * *\end{array}$ & $\begin{array}{l}554 \\
0.19 \\
162.62 * * *\end{array}$ & $\begin{array}{l}466 \\
0.17 \\
125.86 * * *\end{array}$ \\
\hline
\end{tabular}



Table 8 Additional results (II). The relationship between compliance with individual recommendations and the opinion of the audit report

\begin{tabular}{|c|c|c|c|c|c|c|c|}
\hline Variable & Predicted sign & Column A & Column B & Column C & Column D & Column E & Column F \\
\hline REC47 & -(Hypothesis) & $\begin{array}{l}-1.09(- \\
1.68)^{*}\end{array}$ & & & & & \\
\hline REC48 & -(Hypothesis) & & $\begin{array}{l}-0.99(- \\
1.68)^{*}\end{array}$ & & & & \\
\hline REC49 & -(Hypothesis) & & & $\begin{array}{l}1.15 \\
(0.68)\end{array}$ & & & \\
\hline REC50 & -(Hypothesis) & & & & $\begin{array}{c}-0.92 \\
(-1.54)\end{array}$ & & \\
\hline REC51 & -(Hypothesis) & & & & & $\begin{array}{c}0.49 \\
(-0.32)\end{array}$ & \\
\hline REC52 & -(Hypothesis) & & & & & & $\begin{array}{c}-0.60 \\
(-0.68)\end{array}$ \\
\hline SIZE & \pm & $\begin{array}{l}-1.08 \\
(-3.78)^{* * *}\end{array}$ & $\begin{array}{l}-1.05 \\
(-3.72)^{* * *}\end{array}$ & $\begin{array}{l}-1.17 \\
(-4.11)^{* * *}\end{array}$ & $\begin{array}{l}-1.13 \\
(-3.99)^{* * *}\end{array}$ & $\begin{array}{l}-1.18 \\
(-4.14)^{* * *}\end{array}$ & $\begin{array}{l}-1.19 \\
(-4.12)^{* * *}\end{array}$ \\
\hline$A G E$ & - & $\begin{array}{l}-0.41 \\
(-0.60)\end{array}$ & $\begin{array}{l}-0.34 \\
(-0.51)\end{array}$ & $\begin{array}{l}-0.35 \\
(-0.51)\end{array}$ & $\begin{array}{l}-0.41 \\
(-0.60)\end{array}$ & $\begin{array}{l}-0.34 \\
(-0.49)\end{array}$ & $\begin{array}{l}-0.41 \\
(-0.59)\end{array}$ \\
\hline LEVERAGE & + & $\begin{array}{l}3.65 \\
(2.03)^{* *}\end{array}$ & $\begin{array}{l}3.68 \\
(2.06)^{* *}\end{array}$ & $\begin{array}{l}3.36 \\
(1.88)^{*}\end{array}$ & $\begin{array}{l}3.26 \\
(1.84)^{*}\end{array}$ & $\begin{array}{l}3.24 \\
(1.83)^{*}\end{array}$ & $\begin{array}{l}3.20 \\
(1.80)^{*}\end{array}$ \\
\hline LLOSS & + & $\begin{array}{l}1.10 \\
(1.99)^{* *}\end{array}$ & $\begin{array}{l}1.13 \\
(2.08)^{* *}\end{array}$ & $\begin{array}{l}1.13 \\
(2.05)^{* *}\end{array}$ & $\begin{array}{l}1.17 \\
(2.11)^{* *}\end{array}$ & $\begin{array}{l}1.10 \\
(1.98)^{* *}\end{array}$ & $\begin{array}{l}1.12 \\
(2.04)^{* *}\end{array}$ \\
\hline AUDFIRM & + & $\begin{array}{l}-1.15 \\
(-1.31)\end{array}$ & $\begin{array}{l}-1.15 \\
(-1.34)\end{array}$ & $\begin{array}{l}-1.07 \\
(-1.22)\end{array}$ & $\begin{array}{l}-1.15 \\
(-1.30)\end{array}$ & $\begin{array}{l}-1.13 \\
(-1.29)\end{array}$ & $\begin{array}{l}-1.11 \\
(-1.26)\end{array}$ \\
\hline ZMIJW & + & $\begin{array}{l}1.21 \\
(3.17)^{* * *}\end{array}$ & $\begin{array}{l}1.15 \\
(3.02)^{* * *}\end{array}$ & $\begin{array}{l}1.23 \\
(3.14)^{* * *}\end{array}$ & $\begin{array}{l}1.25 \\
(3.23)^{* * *}\end{array}$ & $\begin{array}{l}1.26 \\
(3.23)^{* * *}\end{array}$ & $\begin{array}{l}1.27 \\
(3.24)^{* * *}\end{array}$ \\
\hline$C A C L$ & - & $\begin{array}{l}-0.67{ }^{-} \\
1.88)^{*}\end{array}$ & $\begin{array}{l}-0.62 \\
(-1.73)^{*}\end{array}$ & $\begin{array}{l}-0.62 \\
(-1.76)^{*}\end{array}$ & $\begin{array}{l}-0.67 \\
(-1.89)^{*}\end{array}$ & $\begin{array}{l}-0.64 \\
(-1.80) *\end{array}$ & $\begin{array}{l}-0.64 \\
(-1.82)^{*}\end{array}$ \\
\hline YEAR controls & Yes & Yes & Yes & Yes & Yes & Yes & Yes \\
\hline INDUSTRY controls & Yes & Yes & Yes & Yes & Yes & Yes & Yes \\
\hline
\end{tabular}



Table 6 Additional results (I). The relationship between compliance with individual recommendations and discretionary accruals

\begin{tabular}{|c|c|c|c|c|c|c|c|}
\hline Variable & Predicted sign & Column A & Column B & Column C & Column D & Column E & Column F \\
\hline$R E C 47$ & -(Hypothesis) & $\begin{array}{l}-0.015 \\
(-3.49)^{* * *}\end{array}$ & & & & & \\
\hline REC48 & -(Hypothesis) & & $\begin{array}{l}-0.016 \\
(-3.91)^{* * *}\end{array}$ & & & & \\
\hline REC49 & -(Hypothesis) & & & $\begin{array}{l}-0.000 \\
(-0.01)\end{array}$ & & & \\
\hline REC50 & -(Hypothesis) & & & & $\begin{array}{c}-0.008 \\
(-2.26)^{* *}\end{array}$ & & \\
\hline REC5I & -(Hypothesis) & & & & & $\begin{array}{c}-0.002 \\
(-0.37)\end{array}$ & \\
\hline REC52 & -(Hypothesis) & & & & & & $\begin{array}{r}-0.004 \\
(-0.82)\end{array}$ \\
\hline SIZE & - & $\begin{array}{c}-0.004 \\
(-4.29)^{* * *}\end{array}$ & $\begin{array}{l}-0.004 \\
(-4.04)^{* * *}\end{array}$ & $\begin{array}{l}-0.005 \\
(-5.41)^{* * *}\end{array}$ & $\begin{array}{l}-0.005 \\
(-4.75)^{* * *}\end{array}$ & $\begin{array}{l}-0.005 \\
(-5.32)^{* * *}\end{array}$ & $\begin{array}{l}-0.005 \\
(-5.30)^{* * *}\end{array}$ \\
\hline$A G E$ & - & $\begin{array}{l}-0.007 \\
(-2.05) * *\end{array}$ & $\begin{array}{l}-0.007 \\
(-2.09)^{* *}\end{array}$ & $\begin{array}{l}-0.005 \\
(-1.46)\end{array}$ & $\begin{array}{l}-0.006 \\
(-1.76)^{*}\end{array}$ & $\begin{array}{l}-0.006 \\
(-1.52)\end{array}$ & $\begin{array}{l}-0.006 \\
(-1.55)\end{array}$ \\
\hline LEVERAGE & + & $\begin{array}{l}0.063 \\
(6.55)^{* * *}\end{array}$ & $\begin{array}{l}0.062 \\
(6.53)^{* * *}\end{array}$ & $\begin{array}{l}0.062 \\
(6.46)^{* * *}\end{array}$ & $\begin{array}{l}0.062 \\
(6.47)^{* * *}\end{array}$ & $\begin{array}{l}0.063 \\
(6.53)^{* * *}\end{array}$ & $\begin{array}{l}0.063 \\
(6.50)^{* * *}\end{array}$ \\
\hline GROWTH & + & $\begin{array}{l}0.007 \\
(1.38)\end{array}$ & $\begin{array}{l}0.007 \\
(1.33)\end{array}$ & $\begin{array}{l}0.006 \\
(1.15)\end{array}$ & $\begin{array}{l}0.006 \\
(1.21)\end{array}$ & $\begin{array}{l}0.008 \\
(1.52)\end{array}$ & $\begin{array}{l}0.007 \\
(1.44)\end{array}$ \\
\hline LLOSS & + & $\begin{array}{l}0.015 \\
(3.74)^{* * *}\end{array}$ & $\begin{array}{l}0.015 \\
(3.82)^{* * *}\end{array}$ & $\begin{array}{l}0.016 \\
(4.01)^{* * *}\end{array}$ & $\begin{array}{l}0.016 \\
(3.91)^{* * *}\end{array}$ & $\begin{array}{l}0.016 \\
(3.88)^{* * *}\end{array}$ & $\begin{array}{l}0.016 \\
(3.78)^{* * *}\end{array}$ \\
\hline CFFO & - & $\begin{array}{l}0.008 \\
(3.82)^{* * *}\end{array}$ & $\begin{array}{l}0.081 \\
(3.61)^{* * *}\end{array}$ & $\begin{array}{l}0.082 \\
(3.81)^{* * *}\end{array}$ & $\begin{array}{l}0.080 \\
(3.62)^{* * *}\end{array}$ & $\begin{array}{l}0.088 \\
(3.87)^{* * *}\end{array}$ & $\begin{array}{l}0.082 \\
(3.76)^{* * *}\end{array}$ \\
\hline AUDFIRM & - & $\begin{array}{l}-0.026 \\
(-2.80)^{* * *}\end{array}$ & $\begin{array}{l}-0.027 \\
(-2.92)^{* * *}\end{array}$ & $\begin{array}{l}-0.029 \\
(-3.03)^{* * *}\end{array}$ & $\begin{array}{l}-0.022 \\
(-2.29)^{* *}\end{array}$ & $\begin{array}{l}-0.023 \\
(-2.43)^{* *}\end{array}$ & $\begin{array}{l}-0.023 \\
(-2.40)^{* * * *}\end{array}$ \\
\hline YEAR controls & Yes & Yes & Yes & Yes & Yes & Yes & Yes \\
\hline INDUSTRY controls & Yes & Yes & Yes & Yes & Yes & Yes & Yes \\
\hline
\end{tabular}


Table 7 Results of the multivariate analysis (II). The relationship between the level of compliance with accounting recommendations and the opinion of the audit report

\begin{tabular}{|c|c|c|c|c|c|}
\hline Variable & Predicted sign & Column A & Column B & Column C & Column D \\
\hline COMPLIANCE & -(Hypothesis) & $\begin{array}{l}-2.98(- \\
1.63)^{*}\end{array}$ & & & \\
\hline COMPLIANCEC & -(Hypothesis) & & $\begin{array}{l}-5.82 \\
(-2.30)^{* *}\end{array}$ & & \\
\hline FULLCOMPLIANCE & -(Hypothesis) & & & $\begin{array}{l}-1.06 \\
(-1.96) * *\end{array}$ & \\
\hline FULLCOMPLIANCEC & -(Hypothesis) & & & & $\begin{array}{l}-1.34 \\
(-2.28)^{* *}\end{array}$ \\
\hline$S I Z E$ & \pm & $\begin{array}{l}-1.09 \\
(-3.83) * * *\end{array}$ & $\begin{array}{l}-1.03 \\
(-3.35) * * *\end{array}$ & $\begin{array}{l}-1.11 \\
(-3.84) * * *\end{array}$ & $\begin{array}{l}-1.08 \\
(-3.47) * * *\end{array}$ \\
\hline$A G E$ & - & $\begin{array}{l}-0.44 \\
(-0.65)\end{array}$ & $\begin{array}{l}-0.33 \\
(-0.45)\end{array}$ & $\begin{array}{l}-0.42 \\
(-0.61)\end{array}$ & $\begin{array}{l}-0.17 \\
(-0.24)\end{array}$ \\
\hline$L E V E R A G E$ & + & $\begin{array}{l}3.51 \\
(1.96)^{* *}\end{array}$ & $\begin{array}{l}1.17 \\
(0.64)\end{array}$ & $\begin{array}{l}3.59 \\
(1.98)^{* *}\end{array}$ & $\begin{array}{l}1.09 \\
(0.59)\end{array}$ \\
\hline LLOSS & + & $\begin{array}{l}1.14 \\
(2.06)^{* *}\end{array}$ & $\begin{array}{l}1.04 \\
(1.73)^{*}\end{array}$ & $\begin{array}{l}1.26 \\
(2.24)^{* *}\end{array}$ & $\begin{array}{l}1.19 \\
(1.96)^{* *}\end{array}$ \\
\hline AUDFIRM & + & $\begin{array}{l}-1.14 \\
(-1.29)\end{array}$ & $\begin{array}{l}-0.99 \\
(-1.07)\end{array}$ & $\begin{array}{l}-1.16 \\
(-1.30)\end{array}$ & $\begin{array}{l}-0.96 \\
(-1.03)\end{array}$ \\
\hline ZMIJW & + & $\begin{array}{l}1.22 \\
(3.18)^{* * * *}\end{array}$ & $\begin{array}{l}1.22 \\
(3.16) * * *\end{array}$ & $\begin{array}{l}1.67 \\
(2.99) * * *\end{array}$ & $\begin{array}{l}1.42 \\
(3.13)^{* * *}\end{array}$ \\
\hline$C A C L$ & - & $\begin{array}{l}-0.069 \\
(-1.94)^{*}\end{array}$ & $\begin{array}{l}-0.052 \\
(-1.43)\end{array}$ & $\begin{array}{l}-0.075 \\
(-2.04)^{* *}\end{array}$ & $\begin{array}{l}-0.052 \\
(-1.44)\end{array}$ \\
\hline YEAR controls & Yes & Yes & Yes & Yes & Yes \\
\hline INDUSTRY controls & Yes & Yes & Yes & Yes & Yes \\
\hline Constant & & $\begin{array}{l}10.15 \\
(2.58)^{* * *}\end{array}$ & $\begin{array}{l}11.59 \\
(2.65)^{* * *}\end{array}$ & $\begin{array}{l}7.95 \\
(2.16)^{* * *}\end{array}$ & $\begin{array}{l}7.52 \\
(1.99)^{* *}\end{array}$ \\
\hline \# of observations & & 542 & 462 & 542 & 462 \\
\hline Wald Chi (2) & & $47.06^{* * *}$ & $37.46^{* * *}$ & $46.66 * * *$ & $37.03 * * *$ \\
\hline
\end{tabular}

